\title{
Eğitimin Ekran Üzerinden Teknolojik Dönüşümünde Pandemi Dönemi'nin Etkisi
}

\author{
DOI: $10.26466 /$ opus.777215
}

\author{
Esennur Sirer * \\ * Dr, Üsküdar Üniversitesi, İletişim Fakültesi, İstanbul / Türkiye \\ E-Posta: esennur.sirer@uskudar.edu.tr \\ ORCID: 0000000303454158

\section{Öz}

Teknolojinin ilerlemesi ve dijital uygulamaların yaşam alanına girmesiyle birlikte eğitim alanında da dijitalizasyona geçiş başladı. Bu konuda süregelen çalışmalar teknoloji kullanımını eğitimde yardımo unsur olarak konumlandırlyordu. 12 Mart 2020 tarihinde Dünya Sağllk Örgütü tarafindan pandemi ilan edilmesinin ardından ülkemizde örgün eğitim veren tüm okullar kapatıldı. Bu ani gelişmenin ardindan anaokulundan başlayarak, ilkokul, orta öğretim ve üniversiteler bir hafta gibi klsa bir sürede hızla uygulayageldikleri sistemi değiştirip ekranlar aracılı̆̆ılyla uzaktan dijital eğitime geçti. Örgün öğretimdeki simıflar sanal uygulamalar ile yer değiştirerek ekranlar aracılığıyla simüle edilmeye başlandı. Gerçek sinuflar yerine işlemsel ikizi devreye girmişti ve sanal sınuflardan oluşan simülasyon evreninde teknoloji kullanımı test edilmeye başlandı. Bu dönemde öğrenciler oyun oynadıkları yada boş vakitlerini değerlendirdikleri ekranları eğitim amaçlı kullanır olmuşlardı. Çalışmanın amacl; iletişim teknolojileri aracılı̆̆ıyla sanal ortamda simüle edilen eğitim içeriklerinin hangi ekranlar üzerinden deneyimlendiğini araştırmaktır. Bu bağlamda pandemi döneminde dijital ekranlar aracilığıyla oluşturulan sanal sınıflarda yapılan uzaktan eğitim çalışmaları ele alınmaktadır. Araştırmada; anaokulu, ilkokul, orta öğretim ve üniversite öğrencilerinin okulların kapalı olduğu pandemi döneminde, farklı ekranlar üzerinden ulaştıkları eğitim içerikleri ve sanal sınıf uygulamaları görsel materyaller üzerinden incelenerek betimsel analiz yapılmıştır. Araştırma bulgularında öğrenciler tarafindan televizyon ekranından daha çok yeni medya uygulamalarının kullanıldı̆̆g gözlenmiştir. Etkileşime açık yeni medyanın kullanım alanlarından birisi de bugüne kadar öne çımayan eğitim alanında performatif öğrenmeye uygun yapısıdır. Yeni medya görselleştirme ve simülasyona uygun içeriği desteklemektedir. Böylece kendisinden önce varolan televizyon ekranından daha efektif kullanıma izin vermektedir. 'Akıllı toplum'a kaynaklik edecek yeni nesil örgün eğitime döndüğünde teknolojiyi merkeze alan ve ekranların daha fazla kullanıldığı bir sisteme geçileceği düşünülmektedir.

Anahtar Kelimeler: Dijital iletişim, televizyon, internet, ekran, simülasyon 


\title{
Transformation of Education on Screen
}

\begin{abstract}
With the advancement of technology and the introduction of digital applications into the living space, the transition to digitalization in education began to take place gradually. Studies on this subject positioned the use of technology played a secondary role in education. Following the declaration of a pandemic by the World Health Organization on March 12, 2020, all schools providing formal education in our country were closed. After this sudden development, starting from kindergarten, primary school, middle school, high school and universities changed their systems in a short period of a week and switched to digital education remotely through screens. Classes in formal education began to be simulated through screens by replacing them with virtual applications. Instead of real classes, the operational twin was engaged and the use of technology started to be tested in the simulation universe consisting of virtual classes. In this period, the students used the screens where they played games or spent their times for educational causes. Purpose of the research; the aim of this course is to investigate on which screens the educational contents simulated in a virtual environment through communication technologies are experienced. In this context, distance education studies in virtual classrooms created through digital screens during the pandemic period are discussed. In the research; descriptive analysis was conducted by examining the educational contents and virtual classroom applications that kindergarten, primary school, secondary school and university students accessed through different screens during the pandemic period whwn the schools were closed. In this research findings, it was observed that new media applications were used more than the television screen. One of the areas of use of the new media that is open to interaction is its structure suitable for performative learning in the field of education that we didn't know until today. New media supports content suitable for visualization and simulation. Thus, it allows more effective use than the television screen that exised before it. It is thought that when the new generation formal education that will be a source for the 'Smart Society' returns to formal education, a system that focuses on technology and screens are used more.
\end{abstract}

Keywords: Digital communication, television, internet, screen, simulation 


\section{Giriş}

Dünya Sağlık Örgütü (WHO) Genel Sekreteri Tedros Adhanom Ghebreyesus, 12 Mart 2020 günü bir basın toplantısı düzenleyerek, Covid-19'u pandemik hastalık ilan ettiklerini açıkladı. Pandemi; dünyada aynı anda yaygin biçimde görülen ve çok sayıda insanı etkileyen bulaşıcı hastalıklar için kullanılan bir terim. Bir hastalık sadece Dünya Sağlık Örgütü tarafından onaylanırsa pandemi olarak adlandırılabilmektedir (Hürriyet, 2020). Bu süreçten itibaren sıkça duyulan 'Pandemi' hayatın her alanını etkiledi, eğitim de bundan büyük pay aldı. Birleşmiş Milletler Eğitim, Bilim ve Kültür Örgütü (UNESCO) verilerine göre, 07 Nisan 2020 tarihi itibariyle, Coronavirüs (Covid-19) pandemisi nedeniyle 188 ülkede okullar kapatıldı. Bu durumdan dünya çapında öğrenci nüfusunun yaklaşık olarak \%92'si $(1,576,021,818$ öğrenci) etkilendi (Can, 2020, s.12).

12 Mart 2020 tarihinde dünyada pandemi ilan edilmesinin ardından dört gün sonra 16 Mart 2020 tarihinden itibaren Türkiye'de tüm okullar kapatıldı ve 23 Mart 2020 tarihinden itibaren de anaokulundan lisansüstü eğitime kadar her kademede huzla uzaktan dijital eğitime geçildi. Ani gelişen bu durum karşısında; anaokulları kendi bünyelerinde kurdukları web televizyonları ve web uygulamalarıyla, ilköğretim ve orta öğretimde EBA TV adı verilen ve Milli Eğitim Bakanlığı - TRT'nin işbirliği ile TRT bünyesinde yer alan ayrı ayrı televizyon kanalları ve internet uygulamaları ile, üniversiteler web televizyonları ve web üzerinden görüntülü, sesli katılımı sağlayan çeşitli internet uygulamaları ile eğitim yapmaya başladı. "Milli Eğitim Bakanlığı'nca açıklanan verilere göre, Türkiye'de örgün eğitim alan okul öncesi, ilköğretim ve ortaöğretim düzeyinde toplam 18 milyon 108 bin 860 öğrenci" (Anadolu Ajansı, 2020), Yükseköğretim Kurulu'nun istatistiklerine göre 2 milyon 743 bin 631 öğrenci (YÖK, 2020) okullarda örgün eğitim almaktaydı. Pandemi dönemiyle birlikte tüm dünyada olduğu gibi Türkiye'de de okullarına gidemeyen milyonlarca öğrenci eğitimlerini uzaktan almaya başladı. Böylece yirmi milyondan fazla öğrenci örgün öğretimden bir anda uzaktan dijital eğitime geçiş yapmiş oldu.

Dijital eğitime geçiş ve bunun görüntülü gerçekleştirilmesi uzun zamandır üzerinde çalışılan bir konuydu. 2000'li yıllarda dijitalleşme ile hızlanan ve bireylerin yaşamında önemli bir yer edinen görsellik, eğitim alanında da 
sıkça başvurulan yöntemler arasında yer almaktadır. Örneğin, görsellik çocuklara okuma öğretilirken kullanılan bir yöntemdir. Normal okumada kullanılandan farklı olarak, kelime tanıma yöntemi denilen görsel öğrenmede çocuklar bir kelimeyi resim olarak düşünürler ve direk algı aracilığıyla temsil ettikleri şeyi akıllarında canlandırırlar. Bu bağlamda, görsel olarak temsil etme, gerçeklikten soyutlama sürecinin bir sonucudur (Ellul, 2017, s.198, 200). Gerçeğinin yerine temsilinin konularak gerçekleştirilen eğitim faaliyetleri uzunca bir süredir uygulanagelmektedir. Dijitale geçişle birlikte uygulama alanı da genişlemiştir.

Gerçeğin bir köken ya da gerçek olmayan modeller aracilığıyla tekrar üretilmesine hipergerçek yani simülasyon denilmektedir (Baudrillard, 2018: 14). Baudrillard tarafından geliştirilen simülasyon kuramında, aslı yerine göstergeleri konulmuş bir gerçek, başka bir ifadeyle gerçek süreç yerine işlemsel ikizini koyan bir uzamdan bahsedilmektedir. Bu durumda, gerçek ile hakikat yer değiştirmekte, gerçek sonsuz sayıda üretilebilmektedir. 23 Mart 2020 tarihinden itibaren eğitim alanında gerçek sınıflar yerini sanal sınıflara bırakmış, sanal sınıflarda eğitim ekranlar aracılığıyla simüle edilmeye başlanmıştır. Örgün öğretimde bire bir yaşanan öğrenci öğretmen iletişimi dijital ortamda araya ekranlar konularak simüle edilmiştir. Ekranlar aracılığıyla dijital eğitimin en olumlu tarafı içeriğin yinelenmesi, sonsuz sayıda izlenebilmesidir. Ancak sonsuz sayıda yeniden üretim; gerçeğin biricikliğinin tüm aurası yitip gitmesine neden olmakta (Baudrillard, 2018, s.14,15, kapak), iletişimin o anda orada olabilen biricikliğini yok etmektedir.

Bireysel olarak dijital deneyimin yaşandığı ilk ekran televizyon ekranıdır. Televizyon yaşam alanına girdikten sonra pek çok deneyim üzerinden simüle edilmiştir. Eğitim de bu alanlardan biridir. Türkiye'de okuma yazma seferberliği televizyonda sınıf simülasyonu yapılarak başlatılmıs, yaygın üniversite eğitimi televizyondan ders anlatılarak yaygınlaştırılmıştır. Ancak televizyon yapısı gereği bir eğitim aracı değildir. Çünkü televizyon izlemek dikkat ve yoğunlaşma gerektirmez. Sunulan içerikler yüzeyseldir. Televizyon izleyicisi anlam yerine gösteri istemektedir, içinde bir gösteri olması koşuluyla tüm içeriklere tapmaktadır (Baudrillard, 1991, s.12). Televizyon aracılığıyla bilgilendirme de eğlenceli içeriklerle yapılmaktadır. Bu noktada televizyonun eğlenceli olduğu iddiası eğlenceyi herhangi bir deneyimin temsili için doğal format olarak sunmasından kaynaklanmaktadır (Postman, 1994, s.87). Bu nedenle, televizyonun okuma yazma kültürünü geliştirdiğinden söz 
edilmesi mümkün görünmemektedir. Postman'a göre; tersine okuma yazma kültürüne saldırmaktadır. Eğer televizyon bir şeyin devamıysa, on beşinci yüzyıldaki matbaanın değil, on dokuzuncu yüzyıl ortasında başlayan telgraf ve fotoğrafin devamı (1994, s. 96) olarak görülmelidir.

Hem sözlü hem de yazılı kültürde iletişim öznelerarası bir olgudur. İnsanoğlu uzunca bir süre kendini sözle ifade ettikten sonra yazılı hayata geçilmiştir. Yazı kavramsallaştırmayı sağladığı için bilincin ve öğrenmenin gelişmesinde çok etkileyicidir. Ancak yazı sadece birkaç yüzyıl başat rol oynamış, elektronik iletişim araçları sayesinde insanlar yine konuşur kılınmıştır (Enzensberger, 1979, s.32,33). Geçtiğimiz yüzyıl tek yönlü bir iletişime izin veren kitle iletişim araçlarının öne çıktığı medya ile iletişim (Ong, 2002, s.173) dönemi olmuştur. Radyo ilk iletişim aracı olmasına rağmen televizyon görüntünün gücü nedeniyle öne geçmiştir. Televizyon bir makine olarak gösterileri dört bir yana savurup dağıtmıştır (Baudrillard, 2018, s.15).

“Televizyon sanal bir gerçekliktir. Belli bir andan sonra çocuk kitapların dünyasına dönmekte zorlanacaktır. Televizyon insanlara kımıldamadan oturmayı, çenelerini kapalı tutmayı, dinlemeyi ve elektronik olarak üretilen insan sesi taklitlerinin karşısına geçtikleri zaman duyup gördüklerini edilgen bir biçimde kabul etmeyi öğretir" (Sanders, 2010, s.137). Bir şablon olarak üretilen görsel materyaller bir simülasyondur. Hipergerçek ortamda üretilen bu gerçekler yeni bir gerçeklik düzlemi oluşturmaktadır. "Radyo, televizyon ve daha sonra internet, propogandif etkisi bir yana, etkili bir güç haline gelmesini bu inşa kudretine borçludur" (Karapınar, 2017, s.518). Gerçekten daha gerçekmiş imajı verilerek oluşturulan hipergerçeklik algısı aslında gerçekliğin simülasyonudur. Gerçeğin üretimi arttıkça simülasyon evreni de genişlemektedir.

Baudrillard'ın simülasyon evrenini çözümlemede kullandığı araçlardan biri televizyondur. "Baudrillard günlük yaşamın yeniden üretimini sağlayan yönüyle televizyonu, simülasyon evrenine ait bir araç olarak değerlendirmiştir" (Önk, 2009, s.201). 1981 yılında "Simülakrlar ve Simülasyon" adlı eserini yayınladığı tarihlerde sadece geleneksel medya ve kitle iletişim araçları vardı. Baudrillard medya ile ilgili çıkarımlarını geleneksel medya üzerinden gerçekleştirse de bugün sayısallaşma ile yaşanılan hızlı değişime ışık tutmuş, simülasyon kuramında teknolojiyi önemli bir yere koymuştur. Baudrillard'a göre; "imgenin yok oluşu dijitale geçişle birlikte tamamlanmış" (Baudrillard, 2012, 
s.18), sistematik bir şekilde yok olmuştur. Gelinen noktada; iletişim artık iletişim araçları boyutundan sistem boyutuna ulaşmıştır. Bireyler internet üzerinden etkileşimli bir biçimde iletişim kurmaktadır. Özellikle sosyal ağlar üzerinden gerçekleştirilen iletişim artık yaşamın bir parçası olmuştur. İnternet üzerinden iletişim 1990'lı yıllarda başlasa da internet aracillğıyla kişiler arası iletişimin başladığı 2000'li yıllar teknolojik anlamda etkileşimin başlangıcı sayılmaktadır. Bu dönemde kişiler arası ilişkiler sosyal ağlar aracilığıyla internet ortamına taşınmış, sanallaşmıştır. "Sosyal ağlar web tabanlı olarak çalışırlar ve teknolojik alt yapıları yine bu teknolojinin uygulamalarına dayanır" (Altunay, 2015, s.42). Karşıllıklı etkileşimin gerçekleştiği uygulamalar; fotoğraf, video, ses ve yazılardan oluşan içeriklere sahiptir. "Bu noktada sosyal medya tabirinde geçen sosyal olanın aslında ontolojik olarak bir sosyallikten değil bir simülasyon olarak sosyallikten bahsettiği söylenebilir...Şu haliyle de ne sosyaldir ne de medya bu ikisinin birleşimi olarak ortaya çıkan farklı bir şey; bir simülakrdır" (Metin ve Karakaya, 2017, s.116,117).

Simülasyon, "gerçeğin tüm verilerine sahip olan ama gerçek olmayan şeydir" (Önk, 2009, s.202). Sosyal medyada oluşturulan içeriklerde de teknoloji yardımıyla gerçeğin yerine onun tüm verilerine sahip sanalı konulmaktadır. "İnsanlar etkileşimli, asenkron, zaman ve mekândan bağımsız bir iletişim ortamında akışlara dâhil olmakta, ilerleyen teknoloji sayesinde türlü yetenekler kazanmış araçlar ile gündelik rutinlerini gerçekleştirmektedir" (Özel, 2018, s.67-68). Günümüzde teknik ile görsellik, birçok açıdan birbirine benzer hale gelmiş, görüntüye çok fazla işlev yüklenmiştir (Çakır, 2014, s.105). "Hiçbir teknik, görsel boyutu olmadan varolamayacă̆g" (Ellul, 2017, s.225) için görsel boyut öne çıkarılmakta ve görseller ekranlar aracilı̆̆ıyla yansıtılmaktadır. “Ekranın karşısına geçer geçmez, metin artık metin olarak değil de görüntü olarak algılanmaktadır. Görüntünün akışkan maddesinin içine girilmekte ve bu görüntü değiştirilmeye çalışılmaktadır" (Baudrillard, 2002, s.163). Teknolojinin altyapıyı desteklemesiyle birlikte görüntülerin akış hızı artmış, böylece bireylerin içeriklere ulaşması kolaylaşmıştır. Bu dönemde içeriklere yani görüntüye ulaşmak için televizyon ekranının yanına bilgisayar, tablet ve telefon ekranı da eklenmiştir. Baudrillard'ın sözünü ettiği gerçeğin üretilen bir şey olduğu fikridir. Şu anda istenilen her şey ekranlar aracılığıyla insana bir gerçeklik gibi gösterilebilmektedir (Karapınar, 2017, s.518). Yani simülasyon sanal dünyaya geçişin penceresi olan ekranlar aracilığıyla yapılmaktadır. Bu 
pencerelerin genişlemesi, simülasyon evreninin genişlemesiyle birlikte artmaktadır.

\section{Dijital Eğitim Ekranları}

Teknik kusursuzluk, toplumsal kusursuzluğa örnek olmaktadır. Bundan sonra toplumsal yaşamda hiçbir şey rastlantısal olmayacaktır. Yüzyıllardır süregelen ve günümüzde hızlandırılmış evresi yaşanan, devrimci özelliğe sahip toplumsallaşma böyle bir anlam ifade etmektedir (Baudrillard, 2018, s.60). Teknolojik gelişme toplumsal gelişmeyi de beraberinde getirmiştir. Yaşamın her alanında teknolojinin değiştiriciliği ve dönüştürücülügüünün etkileri görülmektedir. Teknoloji ile dolayımlanmış eğitim anlayışına geçişin örnekleri uzunca bir süredir test edilmektedir. Bunun Türkiye'deki ilk örnekleri TRT'de TRT okul projesi ile 1983 yılında başlamış (youtube, 2020), televizyon o yıllarda başlatılan okuma yazma seferberliğine katkı sağlamıştır. Ardından açık lise ve üniversiteye yönelik açık öğretim dersleri yine kamu kurumu olan TRT ekranında izleyici ile buluşmuştur. O dönemde bant kayıt olarak yapılan dersler bugün pandemi döneminde sıkça başvurulan asenkron eğitimin temelini oluşturmuştur. Daha sonra internet teknolojilerinin sağladığı avantajlar ile önce bilgisayar ortamında ders verilmeye başlanmış, daha sonra bağlantı hızlarının artması ve mobil cihazların gelişimi ile mobil eğitime doğru evrilmiştir (Yamamoto ve Altun, 2020, s.25). Bir simülasyon aracı olan televizyon harici dijital ekranlar da eğitim alanında kullanılmaya başlanmıştır.

Simülasyon ekranlarından televizyon, simülasyonun amacına en çok hizmet eden araçlardan biri olmuştur. Dünyayı eve getiren televizyon ekrandan gerçeğin yerine gerçeğin sesinin ve görüntüsünün deneyimlenmesini sağlayan bir hipergerçeklik sunmaktadır. Televizyon keşfedildiği günden bugüne kadar yayılımını arttırarak yaşamın bir parçası haline gelmiştir. Sürekli ürettiği yapay gerçeklikle gerçeğin yok olma sürecine katkıda bulunmuştur. Televizyon erişimi kolay olan bir iletişim aracıdır. Türkiye'de televizyon sahipliği oran $\% 94,3$ gibi yüksek bir orandır. Türkiye' de günlük televizyon izleme süresi ise; 3 saat 34 dakikadır (RTÜK, 2019, s.29,99).

Ancak televizyonun eğlence içeriklerinden oluşan akışında eğitim programlarına sıkça rastlanmamaktadır. Bu nedenle, pandemi döneminde eğitim içerikli programlar için ayrı kanallar açılmıştır. Pandemi döneminde televiz- 
yondan yürütülen eğitim faaliyetinin tek yönlü ve kitlesel bir eğitimi amaçladığı görülmektedir (Can, 2020, s.28). Televizyon iletişim alanında kolay ulaşılmasının dışında öğrenciler için eski bir mecra olarak kalmış, eğitim çağındaki öğrencilerin isteklerine cevap verememiş, anında iletişim ve geri bildirim konusunda yetersiz kalmıştır. IPTV denilen ve geri bildirime açık internet protokolü televizyonculuğu da altyapı ve donanım eksikliği nedeniyle yeterli ilgiyi görememiştir. RTÜK araştırmasına göre; "evlerinde televizyon izlemek için bulunan bağlantılara bakıldığında; \%79,3'ünün Uydu/Karasal Anten, \%13,4'ünün Kablolu Televizyon, \%9,4'ünün Dijital Platform ve \%0,6'sının IPTV bağlantısı bulunduğu saptanmıştır" (2019, s.102). Pandemi döneminde de öğrenciler sahip oldukları uydu/karasal anten ya da kablolu televizyon aracılığıyla eşzamanlı olarak televizyondan verilen dersleri izlemişler, geri bildirim ve asenkron (eş zamansı) izleme yapabilecekleri IPTV yeterli yayılım alanı bulamadığından eğitim için çözüm olamamıştır.

Yeni medyanın en önemli özelliği etkileşimli olması ve geribildirimlere anında cevap verebilmesidir. Bu durum televizyonun izlenirliğini etkilemektedir. Türkiye'deki internet kullanım oranlarına bakıldığında; son yıllarda televizyon seyretme oranını geçtiği gözlemlenmektedir. “Türkiye'deki 16-64 yaş arası kullanıcılar günde 7 saat 29 dakika internet kullanmaktadır. Türkiye'nin 2020'deki internet penetrasyonu ise yüzde 74 seviyesindedir. Türkiye internet penetrasyonu konusunda dünyada ilk sıralarda yer almiyor olsa da, yüzde 59 seviyesindeki dünya ortalamasından çok daha yukarıda görünmektedir" (We Are Social Digital, 2020). Ayrıca telefon ve tablet gibi mobil ekranlar zamandan ve mekândan bağımsız izleme olanağı sağladığı için internet kullanımını arttırmaktadır.

RTÜK'ün yaptığ1 araştırmaya göre; Türkiye'de gençlerin internet kullanım oranlarının yüksekliği göze çarpmaktadır. İnternet kullanımı 15-24 yaş arasındaki bireylerde \%89,7 oranındadır. Araştırma sonuçlarına göre mobilitenin de özellikle eğitim çağındaki gençler arasında yaygın olduğu gözlemlenmiştir. Türkiye'de mobiliteyi sağlayan telefon, tablet ve bilgisayardan izlenen televizyon yayınlarının aylık ortalama gün sayısının yaşlara göre dağılımına bakıldığında, 15-24 yaş grubundakilerin ayda ortalama 1,1 gün, 25-34 yaş grubundakilerin 0,9 gün, 35-44 yaş grubundakilerin 0,7 gün, 45-54 yaş grubundakilerin 0,3 gün, 55-64 yaş grubundakilerin 0,2 gün olduğu (2019, s.116,139) belirlenmiştir. 
Son verilere göre; dünyada 7 Milyar 750 Milyon insan yaşamaktadır, bunun 4 milyar 540 milyonu internet kullanıcısı, 3 milyar 800 milyonu da sosyal medya kullanıcısıdır" (We Are Social Digital, 2020). Her geçen gün internet kullanımında artış gözlenmesi çocukların ve gençlerin internet kullanımını işaret etmektedir. Şu anda eğitim alan öğrenciler yaş olarak internetin bulunuşundan sonra doğan yani 'digital yerli' olarak adlandırılmaktadır. Doğal olarak internet erişimleri fazla ve olanaklarından yararlanma kapasiteleri yüksektir. Bu durum yaşamlarında ve eğitimlerinde teknolojiyi ve yeni iletişim olanaklarını kolaylıkla benimsemelerini sağlamaktadır. "Etkileşimli beyaz tahtalar, tabletler, akıllı telefonlar, arama motorları ve sosyal medya platformları dahil olmak üzere çeşitli teknolojilerin kullanımı yeni dijital teknolojilerin eğitime getirdiği geniş kapsamlı ve genellikle dikkat çekici değişiklikler eğitim alanında yer alan çok kişinin ilgi alanındadır" (Zahn, vd., 2019). Bu durum pandemi döneminde öğrencilerin dijital ekranlar yoluyla eğitime yönlendirilmelerinde kolaylık sağlamıştır.

\section{Yeni Medya ile Etkileşimli Öğrenme}

İnternet ağları üzerinden ses ve videoların eş zamanlı iletiminin (streaming) mümkün kılınması yayıncılık açısından önemli bir dönüm noktası olmuştur. Akış (stream) sabit ve sürekli bir şekilde veri aktarımı için kullanılan teknik olarak tanımlanmaktadır. İnternetin bir video platformu olarak kullanılması ile birlikte televizyon için üretilmiş içeriklerle birçok araca ulaşabilirliğinin önü açılmıştır (Özel, 2018, s.81). Radyo, televizyon, gazete gibi geleneksel medya araçları dışında kalan ve internet ortamındaki tüm medya içeriklerini kapsayan Yeni Medya, olanakları ve sınırları bakımından sürekli gündemdedir.

Yeni iletişim döneminin en önemli özelliklerinden birisi etkileşimdir. Etkileşim, sayısallaşma ve Yeni Medya ile birlikte ortaya çıkarak teknolojik gelişmelerle de bağlantılı biçimde iletişim kavramına kattığı değişimle hem yayıncılık hem de içerik kavramlarını değiştirmiştir (Bolat, 2020, s.118). 2006 y1lında Avrupa Konseyi tarafından hazırlanan ve RTÜK tarafından Türkçeleştirilerek yayınlanan İnternet Okuryazarlığı El Kitabı'nda; “web sitesi hazırlanması, bilgi araştırılması, e-posta kullanılması, dijital sohbet hizmetleri, haber grupları, dijital veri tabanları, dijital müzik görüntü ve oyun, blog, çevri- 
miçi alışveriş yapılması, e-vatandaş olmak ve uzaktan eğitim için faydalanılması Yeni Medya'nın kapsamında gösterilmiştir" (Binark ve Bek, 2010, s.211,212).

Yeni Medya'nın içinde yer alan ve 2000 sonrası yaşam alanına giren Sosyal Medya bireysel anlamda içerik oluşturulmasına ve bu içeriklerin yayılımına imkân sağlamıştır. "Eğitim aracı olarak sosyal medya, simülasyonlarla eğitimlerin görselleştirilmesi ve hayata yakınlaştırılması anlamında olumlu işlevlere sahiptir. Bugün hemen hemen her düzeyde açık ve uzaktan eğitim imkânlarının lokal ya da global olarak internet üzerinde ve son dönemlerde de Sosyal Medya üzerinde bulunduğuna tanık olmaktayız" (Metin ve Karakaya, 2017, s.119). Sosyal Medya eğitim olanakları ve öğrenme için bir takım fırsatlar sağladığı gibi riskleri de bünyesinde barındırmaktadır. Etkileşimli öğrenmede öğrenci kendi çalışma stilini ve temposunu kendi belirleyebilmektedir. Kendi kendine öğrenme öğrenciye seçme olasılığı tanıdığı ve ilgi alanlarına yönelik keşiflere açık olduğu için daha motive edici olabilmektedir. Görselliğin yoğun olduğu bu öğrenme biçimi geri bildirime de oldukça uygundur. Ancak farklı ekranlardaki farklı enformasyon odaklanmayı ve kavramayı engelleyebilmektedir. Çok fazla enformasyon uyarısı yüzeysel bilgi edinilmesine sebep olabilmekte, "derin okuma"yı engellemektedir. Bilginin serbestçe ulaşılabilir olduğu da bir yanılgidır çünkü bilgiye ulaşmanın yolu bilinmezse temel bilgiye ulaşılamayabilir (Van Dijk, 2018, s.349,350).

\begin{tabular}{|ll|}
\hline \multicolumn{1}{|c|}{ Fırsatlar } & \multicolumn{1}{c|}{ Riskler } \\
\hline • İnteraktif öğrenme & . Tutarlllık ve tartş̧ma eksikliği nedeniyle parçalanma \\
\hline -Doğrudan güdümleme & . Dikkatin ve odağın dağılması \\
\hline $\begin{array}{l}\text {-Keşfederek ve deneyimleyerek } \\
\text { öğrenme }\end{array}$ & . Çoklu görev illüzyonu \\
\hline -Sunum tipi seçenekleri & . Bilginin serbestçe ulaşılabilir olduğu illüzyonu \\
\hline -Görselleştirme ve simülasyon & \\
\hline -İçerikle doğrudan diyalog & \\
\hline$\bullet \quad$ Bütünleyici öğrenme & \\
\hline -Yeni veri türlerinin ilavesi & \\
\hline -Veri türleri ve iletişim modlarının bütünleştirilmesi \\
\hline -Birleşik öğrenme \\
\hline
\end{tabular}

Şekil 1. Yeni Medya ile Öğrenme Kaynak: (Jan Van Dijk, 2018)

Televizyonda yapılan eğitim programlarında bir simülasyon aracı olarak televizyonun çekiciliği kullanılmaktadır. Televizüel anlatımlarında basitlik 
ve açıklığın yanı sıra görüntüsel materyallerle ve ayrıntılarla desteklenmesinin payı büyüktür (Aziz, 1977, s.38). Televizyon uzun bir süre insanların yaşamında ayrıcalıklı bir yere sahip olmuştur. Yeri geldiğinde bilgilendirmiş, bazen duygulandırmış, çokça da kişiye yalnız olmadığını hissettirmiştir. Televizyon söylemini eğlence içerikleriyle doldurarak evdeki bireyin vaktini doldurmuştur. Ancak televizyon ekranı vermek isteği şeyi sınırlandırmakta çerçevelemekte, oluşturduğu çerçevelerle izleyicilerin düşünsel yapısı çerçevelemeye çalışmaktadır (Akmeşe, 2020: 211). Diğer ekranlar denilen bilgisayar, tablet ve telefon yaşam alanına katıldığında, televizyonun aslında sınırladığ 1 alan nedeniyle etkileşiminin yüksek olmadığ 1 keşfedilmiştir.

Dört ekrandan kullanıcısı ile buluşan Yeni Medya kısa sürede benimsenmiş ve televizyon ekranının eski medya olarak adlandırılmasına neden olmuştur. Yeni Medya'nın etkileşimliliği alışılana kıyasla daha aktif ve daha bağımsız bir öğrenme yolu yaratmakta, performatif öğrenmeyi simüle etmektedir (Van Dijk, 2018, s.346). Araştırmalar, çocukların ekranlardan ziyade kitaplardan bilgi alma olasılığının daha yüksek olduğunu gösterse de, ekran ile öğrenme öğrenci memnuniyetini \%91, başarısını da \%82 arttırmakta, çeşitli avantajlar sağlamaktadır. Bunlar:

- Aralıklı öğrenme: Ezberlemeyi optimize etmek için algoritmalar ve tekrar kullanma,

- Anında geri bildirim: Bildiriler \% 92 doğrulukla ve öğretmenlerden daha hızlı bir şekilde derecelendirilebilme,

- Kendi hızında öğrenme: Bir öğrencinin performansını izleyerek ve kişisel ihtiyaçlarına göre yönlendirmedir (Jones, 2020).

$\mathrm{Bu}$ yenilikçi teknoloji, eğitimcileri daha iyi öğrenme için yeni stratejilerle donatırken aynı zamanda iş yüklerini de azaltmaktadır. Bugüne kadar öğretmen odaklı öğrenme medya araçlarının kullanımıyla şekil değiştirmiştir. Öğrenciler Yeni Medya'nın özelliklerini kullanarak zamandan ve mekândan bağımsız eğitim faaliyetlerini yürütmeye başlamıştır. Bir süredir anaokulundan yüksek öğretime kadar eğitimin her kademesinde bu değişim sürmektedir. Şu anda örgün eğitime yardımcı olarak işlev gören dijitale geçiş yeni bir sürecin başlangıcını işaret etmektedir. Bu anlamda okulun ve öğretmenin tanımı yeniden yapılacak, yaptığı faaliyetler rehberlik hizmeti olarak işlev görmek üzere yeniden düzenlenecektir. Van Dijk, eğitim sisteminin dönüşmesi anlamına gelen bu durumun tamamlanması için tahminen iki veya üç nesil geçmesinin gerekeceğini söylemektedir (2018, s.346). 
Günümüzde eski ve yeni medyanın, medya yapımclarının ve tüketicilerinin etkileşim halinde olduğu bir yakınlaşma kültürü dönemi yaşanmaktadır. Bu durum medya tüketicilerinin yararınadır, ancak durumu fark etmek ve lehte kullanmak önemlidir (Jenkins, 2018, s.385). Yoksa eğitim alanında teknolojinin belirgin etkilerinin ötesinde toplumsal yaşamı biçimlendirici etkilerini (Aydoğan vd., 2005) görmezden gelmek, teknolojinin tamamen nötr bir alan olarak ifade edilmesi anlamına gelir ve eleştirel yaklaşımın önünü kapatır. Bu bağlamda; 'eski'ye göre şekil, içerik ve yapı olarak değişiklikler içeren yeni medyanın hem olumlu hem de olumsuz özellikleri mevcuttur (Arda, 2020: 2939). Eğitimde geleceği derinden yaklaşan bilgi teknolojileri belirleyecektir ancak bu teknolojilerin doğru kullanımı yetenekli ve özverili öğretmenlerin ellerindedir. Erişimin kolay olduğu yeni bilgi teknolojileri eğitim sürecini büyük ölçüde geliştirmektedir. Önemli nokta, öğretmenlerin ve ebeveynlerin ortak çabalarıyla teknolojinin doğru kullanımını özendirmek olmalıdır. Yoksa üstel artış hızıyla karşı konulamaz bir teknoloji öğrencileri toplumla âlâkasız hale getirebilir (Williams, 2002, s.65).

Çocuklar ve gençler dünyadaki tüm internet kullanıcılarının üçte birini oluşturmaktadır. Bu nedenle ebeveynlerinden daha hiper bağlantılı ve dijitale yatkın olmaları şaşırtıcı değildir. 1.400 eğitimcinin katıldığı bir ankette, ankete katılanların çoğunluğu geleceğin sınıflarının kişiselleştirilmiş öğrenmeye odaklanacağına inandıklarını söylemiştir (Jones, 2020). Türkiye'de 2019 yılında yapılan bir araştırmada; çocukların ortalama olarak günde 2 saat 18 dakika televizyon izledikleri saptanmıştır. Ancak çocukların sadece \%40'1 sadece televizyon ekranın kullanmaktadır. \%60'1 Youtube, \%39'u Facebook, \%24'ü de WhatsApp gibi Sosyal Medya mecralarını kullandığı tespit edilmiştir (Tuğrul, 2019). Çocukların ekran kullanım oranının oldukça fazla olduğu görülmektedir. Bu durumun olumluya döndürülmesi gerekmektedir. Avrupa Komisyonu'nun Avrupa'daki okullarda dijital eğitim konulu raporuna göre Türkiye; Belçika, Litvanya, Hollanda, Bosna Hersek ve İzlanda ile birlikte dijital eğitim sistemiyle ilgili stratejisi olmayan altı ülkeden biri (Eurydice Report, 2019, s.82) olarak görünmektedir.

\section{Amaç ve Yöntem}

12 Mart 2020 günü Covid-19'un pandemik bir hastalık ilan edilmesinin ardından Türkiye'de 23 Mart 2020 tarihinden itibaren örgün eğitimin her kademesinde uzaktan eğitime geçilmiş ve eğitim ekranlar aracılı̆̆ıyla tamamen dijital 
olarak yapılmaya başlanmıştır. Çalışmanın amac1; simülasyon kuramı perspektifinde iletişim teknolojilerinin eğitim içeriklerini dönüştürücü etkilerini ele almaktır. Pandemi döneminde 23 Mart 2020 ile 24 Nisan 2020 tarihleri arasındaki bir aylık bir sürede sanal sınıflar aracılığıyla yapılan uzaktan eğitimin hangi ekranlar kullanılarak simüle edildiği araştırılmıştır.

Bu bağlamda; okul öncesi, ilköğretim, orta öğretim ve yüksek öğretim olmak üzere eğitimin farklı kademelerinde dijitale geçiş sürecinin niteliksel açıdan ele alındığı bir çalışma gerçekleştirilmiş, rastgele seçilen ve incelenen görsel malzemeler betimsel analiz yöntemiyle yorumlanmıştır.

Çalışmanın sonunda ekranlar aracılığıyla gerçekleştirilen dijital eğitim konusunda durum tespiti yapılmış, gelecekte olası uygulamalar için yol gösterici olacağı düşünülerek konuyla ilgili önerilerde bulunulmuştur.

\section{Bulgular ve Değerlendirme}

World Education Blog'da yayınlanan verilere göre; dünyadaki 138 ülkede yaklaşık 1,3 milyar çocuk ve genç okulların kapatılmasından etkilendi. Bu durum dünya nüfusunun \%80'ini etkiledi (2020). Pandeminin etkisinin azalmaya başlamasiyla birlikte “6 Nisan'da Japonya, 15 Nisan'da Danimarka, 20 Nisan' dan itibaren Norveç, Mayıs ayının ilk haftası itibarıyla Almanya ve Çin kademeli olarak okulları yeniden açmaya başladı. Diğer taraftan ise pandemi ile boğuşan İtalya gibi bazı ülkeler bu öğretim yılını kapattıklarını açıkladılar" (Çelik, 2020).

Pandemi döneminde uzaktan eğitim programları planlamak ve tüm paydaşları harekete geçirmek için devlet kurumları, ebeveynler, öğrenciler, öğretmenler ve yöneticiler olmak üzere hedeflenen tüm gruplar için uzaktan eğitim konusunda farkındalık kampanyaları veya iletişim stratejileri başlatıldı. Çin, Arjantin, Kosta Rika, Fransa, Hırvatistan, İran İslam Cumhuriyeti, Kore Cumhuriyeti, Peru, Senegal, Ruanda, Tayland, Meksika, Suudi Arabistan, İspanya ve Vietnam gibi ülkelerde öğretmenler ve öğrenciler arasındaki iletişimi sürdürmek amacıyla eğitim için ayrılan televizyon kanalları dışında sürekli öğrenme için çevrimiçi platformlarını ve mevcut internet uygulamaları devreye sokuldu. Çin' de düşük gelirli ailelere sahip öğrencilere bilgisayar desteği, öğrencilere mobil veri paketleri ve telekomünikasyon sübvansiyonları sağlandı. Fransa'da öğrencilere eğitim döneminde kullanmaları için bilgisayar temin edildi. Birleşik Arap Emirlikleri'nde öğretmenler ve öğrenciler 
için eğitimlerinde herhangi bir zorlukla karşılaşmaları durumunda teknik destek hattı oluşturuldu. Amerika Birleşik Devletleri'nin Washington eyaletinde, okulların çevrimiçi öğrenme hizmetleri sunması için adil erişim sağland1. Portekiz'de, tüm öğrencilere evden internet erişimi ve ücretsiz postane hizmetleri sunuldu.

Bazı ülkelerde öğrencilere teknolojik destek yanında eğitimlerini yürütebilmeleri için kolaylıklar da sağlandı. Örneğin, Çin bazı sınavları çevrimiçi gerçekleştirdi. Japonya ve Tayland'ta sınava katılanların güvenliğini sağlamak için bir kerede sınırlı sayıda öğrencinin sınava alınması gibi özel düzenlemeler yapıldı. İspanya, Kore Cumhuriyeti ve Vietnam'da okul takvimleri kayıp günleri de kapsayacak şekilde ayarlandı. Amerika Birleşik Devletleri'nde Florida ve Washington gibi bazı eyaletlerde, 2019-2020 öğretim yılı için tüm sinavlar iptal edildi. Şili'de öğretim kadrosunda olanlar dijital eğitim konusunda çevrimiçi ögrretim ve yönetim üzerine web seminerleri düzenleyerek deneyimlerini paylaştılar (World Education Blog, 2020).

Türkiye'de yapılan uygulamalar; okul öncesi uygulamalar, ilköğretim uygulamaları, ortaöğretim uygulamaları, yüksek öğretim uygulamaları olarak farklı kademelerde değişik şekillerde uygulandı. Aşağıda yer alan fotoğraflar rastgele örneklem metoduyla seçilmiş ve betimsel analiz yapılmıştır.

\section{Okul Öncesi Eğitim Uygulamaları}

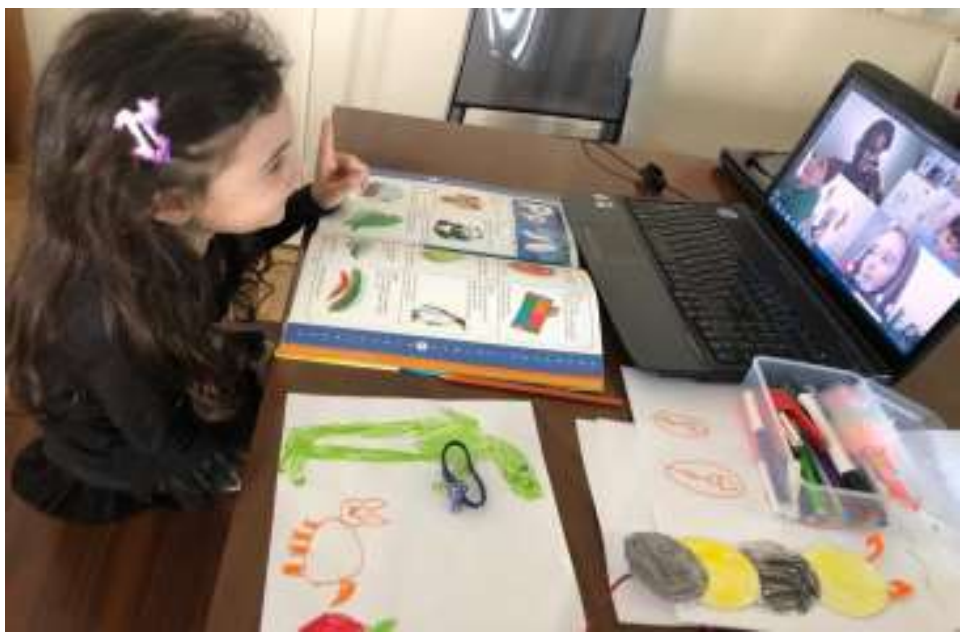

Fotoğraf 1 Anaokulu öğrencisinin zoom uygulaması ile yaptı̆̆ı ders. 
Türkiye'de altı yaşının altında olan anaokulu çağındaki öğrenciler, Milli Eğitim Bakanlığı'nın zorunlu eğitim programı kapsamında olmadığı için ailelerinin yönlendirmesi ile özel ya da devletin çatısı altında hizmet veren çeşitli anaokullarında okul öncesi hazırlık eğitimlerini almaktadır. Pandemi döneminde internet erişimine sahip anaokulu öğrencilerine EBA canlı sınıf uygulaması ve okullarının internet sayfaları aracılığıyla günün belli saatlerinde eğitim verilmiştir. Yukarıdaki fotoğrafta görüldüğü gibi, öğrenciler daha önceden aynı sınıfı paylaştıkları öğretmenleri ve arkadaşlarıyla bilgisayar ekranı aracılığıyla görüşmekte, sanal sınıflarında keyifli vakit geçirmektedir. Okulların kendi web sayfaları ya da 'zoom uygulaması' üzerinden aynı ekranda buluşturulan öğrenciler sanal ortamda birbirlerini görerek iletişim kurmaktadır. Yaptıkları ödevler öğretmenleri tarafından internet üzerinden kontrol edilmekte sanal ortamda yapılan paylaşımlar öğrenciler için ilgi çekici ve eğlenceli kılınmaktadır. Anaokulu öğrencileri tarafından gerçek olarak algılanan sanal sınıf ortamı öğrenciler için simulakr'dır. Fotoğrafta görüldüğü gibi, sınıfta olduğunu düşünerek parmak kaldıran öğrenci gerçek ortamın dijital ikizinde ekran üzerinden dijital eğitimi deneyimlemektedir. Anaokulu çağında eğitimin simülasyonunu yapan öğrenciler için gelecekte bu tür uygulamalara alışmak zor olmayacaktır.

Ancak fotoğrafta görülen anaokulu öğrencisi gibi, öğrencilerin bu etkileşime sahip olabilmesi için üzerinden iletişim kuracakları bilgisayar ya da tablet gibi bir ekrana ve video akışına izin veren internet erişimine sahip olması gerekmektedir. Bu da aileler için bir maliyettir. Dünya ile etkileşimi sağlayan televizyon ve bilgisayar ekranları kullanımı belirli bir maliyet gerektirmektedir (Bajcsy, 2002, s.7). Yani isteyen dilediği anda bu hizmetten faydalanamamaktadır. Bu durum teknoloji dolayımlı eğitim hizmetinden faydalanma konusunda fırsat eşitliği olmadığı konusuna da dikkat çekmektedir.

\section{İlköğretim Uygulamalar}

Her öğrencinin internet erişimi bulunmadığı göz önüne alınarak, Milli Eğitim Bakanlığı 23 Mart 2020 tarihi itibarıyla kamu kurumu TRT'nin üç ayrı kanalından televizyon ekranı aracılığıyla öğrencilerin canlı ders işlemelerini sağlamıştı. Bir hafta sonrasında sanal sınıflar internet ortamına taşınarak EBA üzerinden derslerin tekrar izleme olanağı da sağlandı. Böylece bu yeni yolculukta eğitim devlet eliyle dijital ekranlara taşınmış oluyordu. Millî Eğitim 
Bakanı Ziya Selçuk, 28 Mart 2020 tarihinde yaptığı açıklamada; teknolojik Eğitim Bilişim A $\breve{ı}(E B A)$ 'nın televizyon ve internet aracılığıyla öğrencilere hizmet verdiğini açıklamıştı:

"Bu, hepimiz için yeni bir deneyim, yeni bir yolculuk, yeni bir durum...Entegre uzaktan eğitim yaklaşımıyla, bir; TRT EBA TV yayın programlarını, iki; EBA'yı internet üzerinden öğrencinin kendi başına kullanımını, üç; öğretmen ve öğrencinin buluşabileceği EBA Canlı Sınıf uygulamasını devreye aliyoruz" (MEB, 2020).

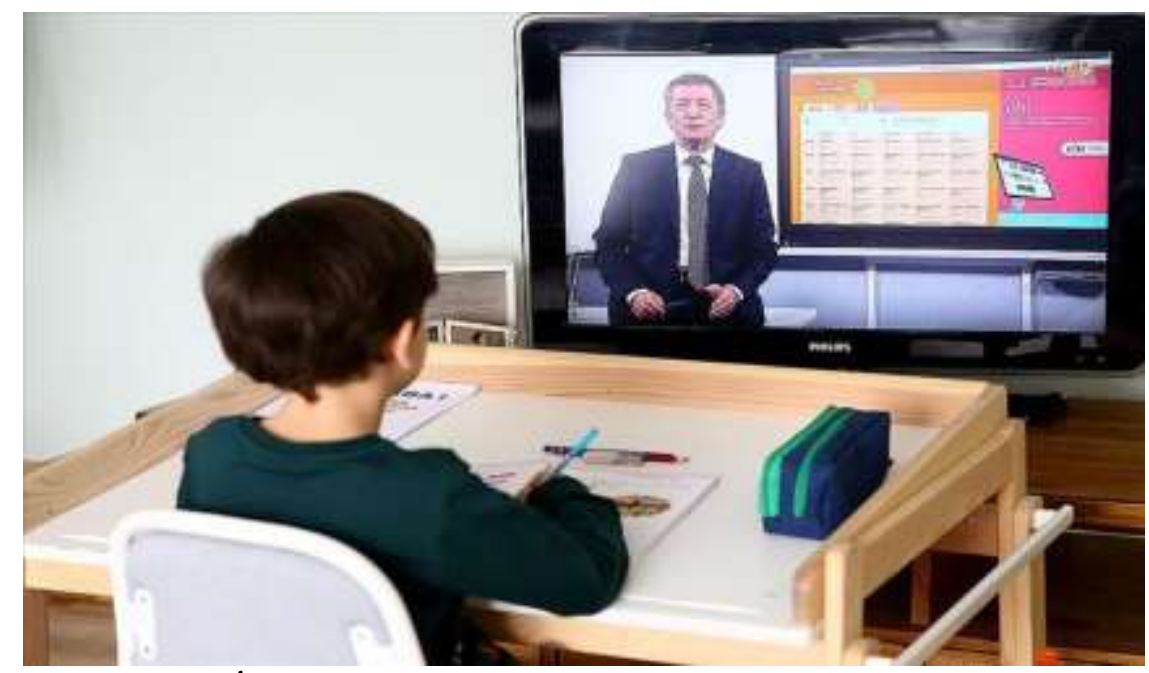

Fotoğraf 2 İlköğretim öğrencisinin EBA TV ile yaptı̆̆ı ders (Bianet, 25.03.2020).

İlkokul, ortaokul ve lise öğrencileri TRT'nin üç farklı televizyon ekranından belirlenen saat dilimleri içerisinde derslerini takip edebilmektedir. İnternetten etkileşimli öğrenmenin olmadığı durumlarda; "öğrencilere eğitim içeriğinin iletilmesi için televizyon, radyo, podcast, DVD ve öğrenme paketleri gibi diğer yöntemler kullanılmalıdır. Bu içeriğin öğrencilere tepki ve etkileşim için fırsat sağlamak üzere tasarlanması gerekir. Ayrıca öğretmenler tarafından yeterli derecede rehberlik ve destek olmaksızın, öğrencilerin kendi kendilerine çevrimiçi öğrenme dünyasında yol bulabilmeleri çok düşük bir ihtimaldir" (Reimers ve Schleicher, 2020, s.8,21). Uzaktan sanal eğitim alan öğrenciler için öğretmenlerin rehberliği önem arz etmektedir. Çünkü bilginin 
serbestçe dolaştığı ve arandığı anda doğru bilgiye ulaşılabilir olduğu bir illüzyondur.

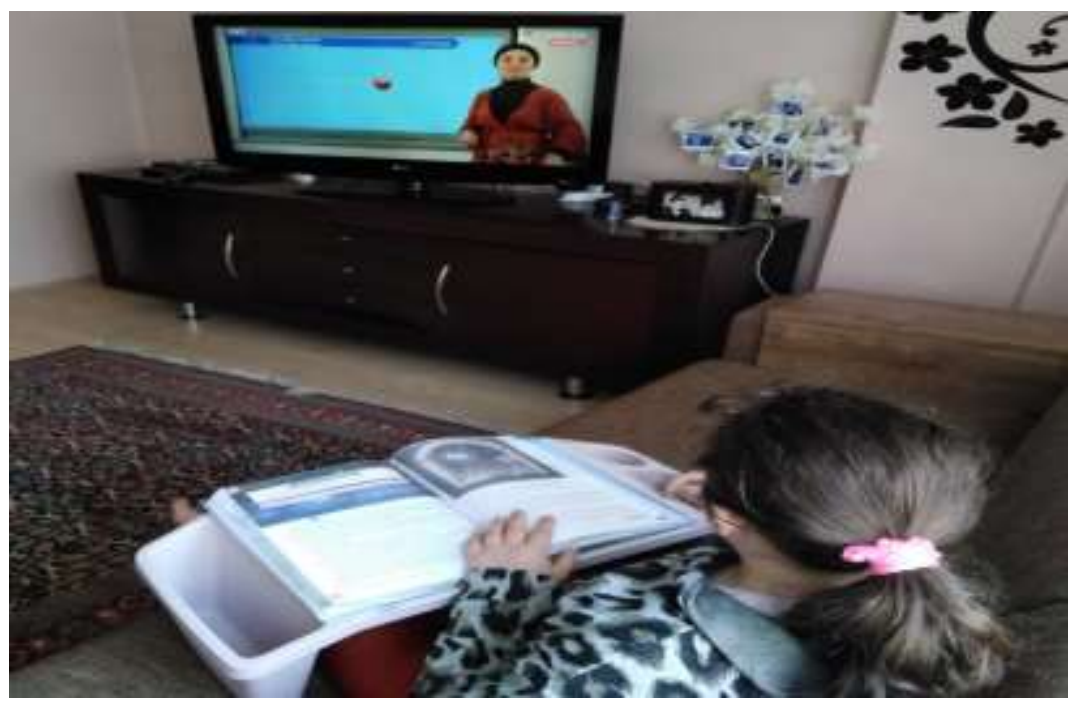

Fotoğraf 3 İlköğretim öğrencisinin EBA TV ile yaptı̆̆ı ders.

Her evin baş köşesinde konumlandırılan televizyon pandemi döneminde her öğrenciye günde en az iki saat ayrılmak durumunda kalmıştır. Ayrıca ergonomik olarak da öğrencilerin sınıfta ders işleme modunda olmaları gerekmektedir. Bu bağlamda; televizyon ekranından ders anlatımı didaktik kalmakta, eğlenceli içeriklerle ve görsellerle sürekli süslenmesi gerekmektedir. Fotoğraftaki öğrencinin dersi kitabından da rahatlıkla takip edebilmesi ve not alabilmesi için okuldaki sırasına benzer ayrı bir düzeneğe ihtiyaç duyduğu görülmektedir. Televizyon yaşam alanına girmesinden bu yana eğlence içeriklerinin yer aldığı, genellikle ailece izlenegelen bir kitle iletişim aracı olduğu için ses sistemi olarak kişiselleştirmeye çok fazla uygun değildir. Bu nedenle öğrencilerin televizyondan canlı ders takip ettikleri zaman diliminde evde yapılan gürültü ve hareket konsantrasyonlarını bozabilmektedir. Aileler çocuklarının rahat çalışabilmesi için özel yaşam mahallerini terk etmek durumunda kalabilmekte ya da sınıf ortamının yaratılabilmesi için ev işlerini öteleyip, sessizlik sağlamaktadır.

Belirlenmiş yayın saatlerinde izleme zorunluluğu haricinde EBA TV hemen her öğrencinin ulaşabileceği teknolojik yapıdadır. Yaklaşık bir yüzyıldır 
varlığını sürdüren televizyon dünyadaki tüm evlere girmiş bir ekrandır. RTÜK verilerine göre; Türkiye'de televizyona sahiplik oranı yaklaşık \%95 (2019, s.29) olduğu için Milli Eğitim Bakanlığı'nın örgün eğitim alan büyük bir öğrenci grubuna bu ekrandan eğitim vermeye başlaması kapsayıcılığı açısindan etkili bir hamle olmuştur.

\section{Ortaöğretim Uygulamalan}

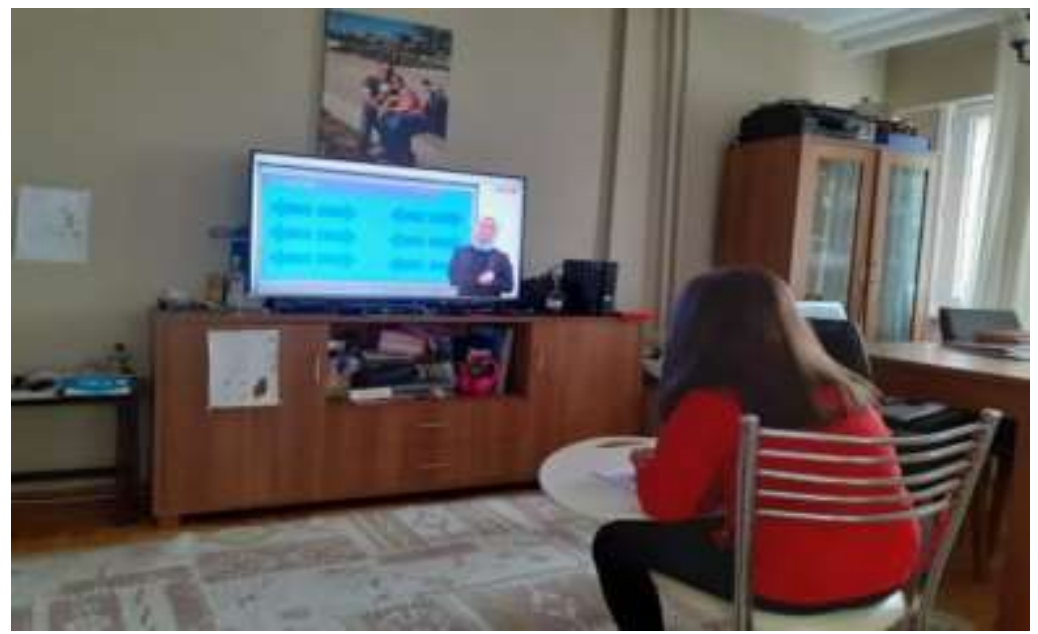

Fotoğraf 4 Ortaöğretim öğrencisin EBA TV ile yaptı̆̆ı ders (Bianet, 25.03.2020).

Milli Eğitim Bakanlığı dijital eğitime geçilen ilk bir aylık süreçte bin saatin üzerinde yayın yaptı̆̆ını açıklamıştır. "eba.gov.tr'nin yanı sıra uzaktan eğitim yapılan EBA TV İlkokul'da son 29 günde 337 saat, EBA TV Ortaokul'da 29 günde 341 saat, EBA TV Lise'de ise 28 günde 400 saat olmak üzere toplam 1078 saat yayın yaptı̆̆ını" (Hürriyet, 2020) belirtmiştir.

Milli Eğitim Bakanlığı orta öğretimde pek çok temel dersi TRT işbirliği ile orta okul ve lise olarak iki ayrı kanaldan yayınlamıştır. Televizyon ekranı etkileşimi en az olan ekrandır. Bu nedenle televizyon izlerken ikinci yada üçüncü ekran kullanılarak etkileşim sağlanmaktadır. Çoklu ekran özellikle gençler tarafından daha fazla kullanılmaktadır. "Çoklu ekran kullanımının yaşlara göre dağılımına bakıldığında, sırasıyla \%28,2 oranıyla 15-24, \%24,7 oraniyla $25-34, \% 20,1$ oraniyla $35-44, \% 14$ oraniyla $45-54$ ve $\% 9,4$ oraniyla 55 ve üstü yaş grubunun yer aldığı görülmüştür. Başka bir deyişle, yaş düştükçe çoklu ekran kullanımı artmaktadır" (RTÜK, 2018, s.153). 


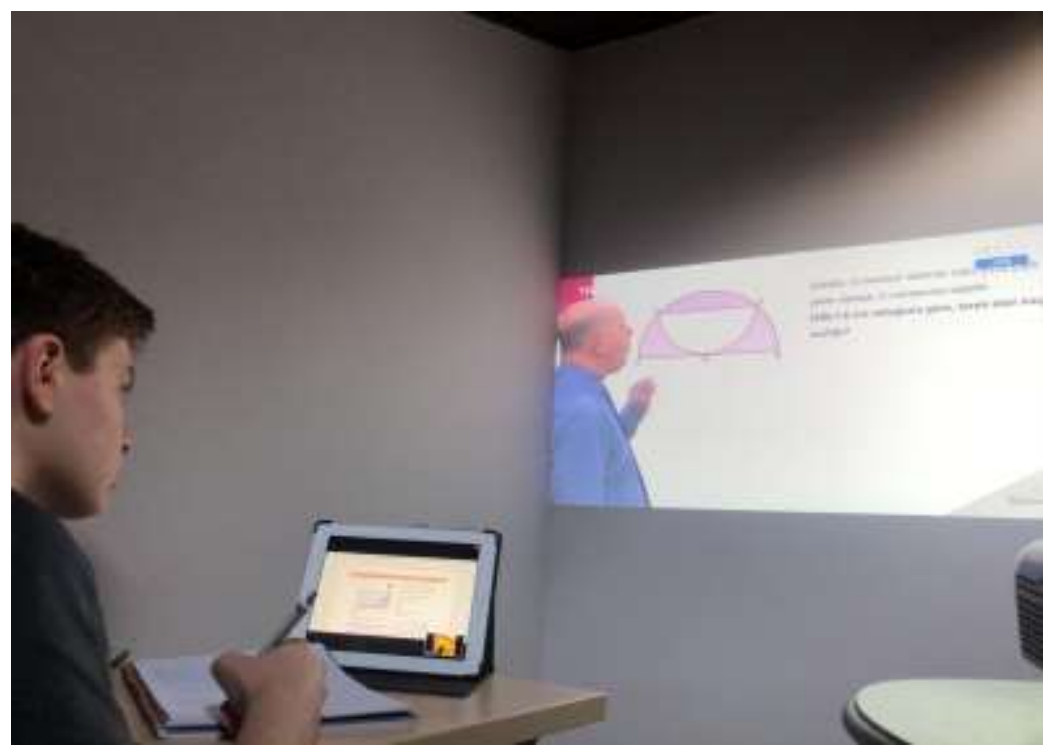

Fotoğraf 5. Ortä̈ğretim öğrencisin EBA TV internet uygulaması ile yaptı̆̆ı ders.

EBA TV'deki içeriklere erişim sadece televizyon ekranı değil, internet vasitasıyla diğer ekranlar üzerinden de gerçekleştirilmektedir. Milli Eğitim Bakanlığı'nın yaptığı bir araştırmada; 23 Mart - 30 Nisan haftasında “EBA'nın 1.2 milyar kez tıklandığını, bunun yüzde 66'sının mobil cihazlar, yüzde 29'unun bilgisayar, yüzde 5'inin tablet üzerinden gerçekleştirildiğini, EBA'y1 aktif kullanan öğrenci sayısı 6 milyon 90 bin 383, öğretmen sayısı ise 900 bin 188" olduğunu belirtmiştir (Hürriyet, 2020).

Yukarıdaki fotoğrafta görüldüğü gibi internet üzerinden EBA TV'ye erişim sağlayan öğrenciler kullandığı ikinci ekran olan tablet yada akıllı telefon ile sosyal medya uygulamaları aracılığıyla öğretmenleri ve arkadaşlarıyla etkileşime geçebilmektedir. Etkileşimli olmadığı için televizyon ekranında ders anlatan öğretmene soramadığı sorularını ikinci ekrandan kendi öğretmenine yönlendirebilmektedir. Öğrencilerde yaş ilerledikçe teknolojik araçları kullanım becerisi ve sahiplik oranının arttı̆̆ gözlenmektedir. Fotoğrafta projeksiyon aleti vasıtasıyla ekranı istedikleri boyutta kullanabildikleri de gösterilmiştir. Simülasyon evrenindeki öğrenciler ikinci ekran üzerinden hem sanal sınıfı hem de etkileşimi deneyimlemektedir. 


\section{Yüksek Öğretim Uygulamalar}

Türkiye'de 23 Mart 2020 Pazartesi gününden itibaren uzaktan eğitim kapasitesine sahip olan bütün üniversitelerde dijital imkânlar ile uzaktan öğretim süreci başlatılması karara bağlanmıştır (Yamamoto ve Altun, 2020: 29). 20182019 öğretim yılında 69 devlet üniversitesinde uzaktan eğitim merkezi yer almaktadır. "YÖK verilerine göre ise, halen Türkiye'de 123 üniversitede UZEM (Uzaktan Öğretim Uygulama ve Araştırma Merkezi) bulunmaktadır. Bu sonuç, YÖK'ün verilerine göre, Türkiye'de 207 Üniversitenin henüz 84 'ünde UZEM bulunmadığını ortaya koymaktadır" (Can, 2020, s.35). Ayrıca varolan UZEM'in internet altyapısı da aynı anda bütün öğrencilerin erişimine olanak sağlayacak yapıda olması gerekmektedir.

Üniversitelerin uzaktan erişim imkânı sağlamalarının yanında öğrencilerin uzaktan erişime ulaşmaları da önemlidir. Pandemi döneminde üniversite öğrencileri arasında yapılan bir araştırmada; öğrencilerin sadece \%63'ünün evinde internet bağlantısı bulunduğu, \%66'sında bilgisayar veya tablet bulunduğu tespit edilmiştir. Yani öğrencilerin üçte birlik bölümü bilgisayar ve tablete sahip değildir. Öğrencilerin uzaktan erişimli eğitimlerini \%64'ünün bilgisayar veya tabletlerinden; \%32'sinin akıllı telefonlarından sürdürdüklerini; \%23'ü ise uzaktan eğitime katılamadıkları bulunmuştur (Karadağ ve Yücel, 2020, s.3).

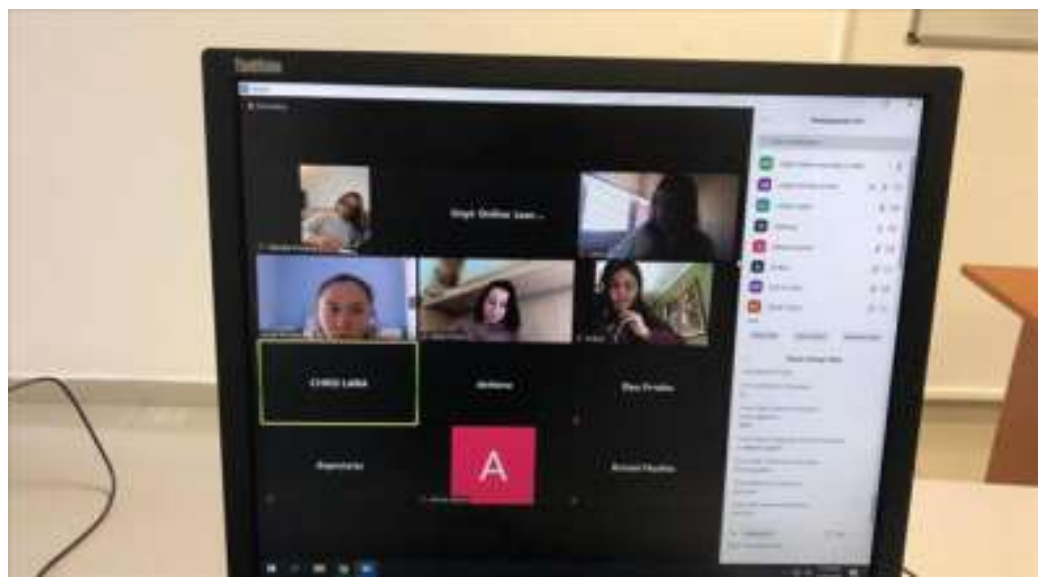

Fotoğraf 6 Üniversite öğrencilerinin 'e-learning online' üzerinden yaptığı ders (Anadolu Ajansı, 17.03.2020) 
Üniversite öğrencileri için karşılıklı konuşma ve tartışma olanaklarına sahip olması ilerideki yaşamlarına sşık tutması ve birey olarak konumlandırılmaları için önem taşımaktadır. Bu nedenle yüz yüze iletişimin ekranlar aracllığıyla yapıldığı pandemi günlerinde bir takım internet uygulamaları kullanılmaya başlanmıştır. Bu uygulamalar üniversite bünyesinde kapalı kaynak uygulamaları olabildiği gibi bilindik uygulamalar da olabilmektedir. Bunlar üniversitelerin uygulayageldikleri sistem ile entegre olabilen internet uygulamalarıdır. "Google Meet, Google Hangout, Zoom, Cisco Webex, Bigbluebutton gibi çevrimiçi video konferans uygulamaları çevrimiçi canlı video eğitim uygulamaları olarak kullanılmaya başlanmıştır" (Yamamoto ve Altun, 2020, s.33).

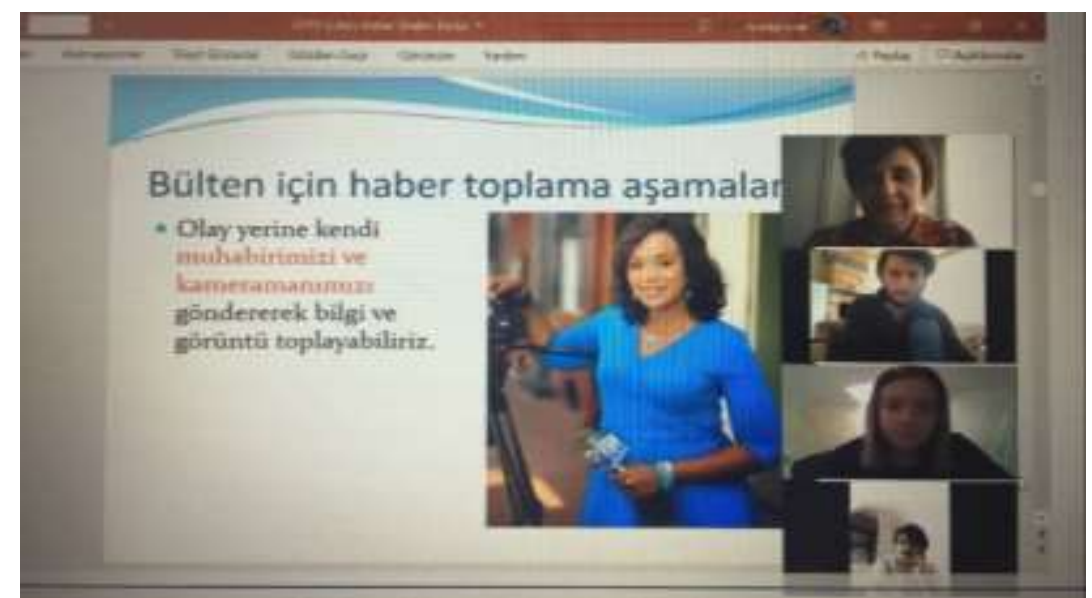

Fotoğraf 7 Üniversite öğrencilerinin 'zoom' uygulaması ile yaptı̆̆ ders.

Fotoğrafta eğitimci ve öğrenciler "zoom uygulaması" üzerinden ders işlemektedir. Öğrenciler hocalarının yetkisi ile sanal sınıfa görüntülü ve sesli katılabilmekte, karşılıklı iletişimde bulunabilmektedir. Ekran düzeni istenilen şekilde oluşturulabilmekte, hoca anlatacağı dersle ilgili görselleri öğrencileri ile eş zamanlı paylaşabilmektedir. Söz alan öğrenciler ekranda sırasıyla görünmekte, yine hocanın yönlendirmesi ile ekran paylaşımı yapılabilmektedir. Bu uygulama özelinde katılımcı sayısı yüz kişiye kadar çıkabilmektedir. Dersi planlayan hoca daha önceden öğrencilerine bu ekrandan derse katılabilmeleri için link göndermekte, öğrenciler de bu link aracilığıyla kolayca derse dâhil olabilmektedir. 
Canlı olarak gerçekleştirilen sanal sınıf uygulaması katılamayan öğrencilerin izlemesi için kayıt edilmekte, verilen linkten istenildiği zaman istenilen ekrandan tekrar izlenmesi mümkün olmaktadır. Teknoloji dolayısıyla öğrencilere bir olanak daha sağlanmakta, sanal ortamda senkron yada asenkron işlenen derslere istenildiği zaman istenilen yerden ve istenilen ekrandan ulaşılabilmektedir. Üniversiteler kendi içlerinde derslere katılım ve tekrar izlenmesi yoluyla sanal sınıf uygulamalarından alınan verimi sayısal verilerle analiz etmeye çalışmaktadır. Bu durum her ne kadar niteliksel analize uzak olsa da sınıf simülasyonları özellikle üniversitelerin gelecekteki yapılanmasına ışık tutacak gibi görünmektedir.

\section{Sonuç}

12 Mart 2020 tarihinde başlayan pandemi dönemiyle birlikte sadece sağlık alanı değil, yaşamın hemen her alanı etkilendi. Milyonlarca kişiyi etkileyen alanlardan birisi de eğitimdi. Dünya çapında yaklaşık 1,5 milyar, Türkiye'de de yaklaşık 20 milyon öğrenci bu dönemde örgün eğitim aldıkları okullarından ayrı kaldı. Pandemi sürecinin iki haftayı geçmesinin ardından dünyada olduğu gibi Türkiye'de de senkron (eşzamanlı) yada asenkron (eş zamansız) sanal sınıf uygulamaları ile uzaktan eğitim sürecine hızla geçildi. Dünyanın hemen her ülkesinde öğrenciler için eğitim alabilecekleri ulusal televizyon kanalları açıldı. Ancak etkileşimi ve geri bildirimi sınırlı olan bu yayınlar öğrenciler için yeterli değildi. Bu dönemde Yeni Medya ile eğitim olanakları uzaktan çevrimiçi eğitim için bir çözüm olarak ortaya çıkmıştı. Öğretmenler ve öğrenciler ilişkilerini dijital ortamdaki eğitim platformları ve sosyal medya uygulamaların kullanarak sürdürdü.

Yaşanan pandemi döneminde eğitimde dijitalizasyona geçişin hızlanması, eğitim sisteminin teknoloji bağlamında yeniden yapılandırılmasının önünü açmış görünmektedir. Dünya Sağlık Örgütü tarafından pandemi ilân edilmesinin ardından kısa sürede eğitimde dijitale geçiş konusunda farklı uygulamaların hayata geçirildiği gözlemlendi. Görüntünün ve internet uygulamalarının öne çıktığı bu dönemde, Baudrillard'ın simülasyon evrenindeki gibi, teknoloji ile dolayımlanmış yeni eğitim içerikleri oluşturuldu, bu içerikler ekranlar aracılığıyla test edildi. Yani teknoloji aracılığıyla eğitime erişimin simülasyonu yapıldı. Pandemi ile birlikte Baudrillard'ın sözünü ettiği gerçeklikten tamamen farklı bir gerçeklik gerçeğe yaklaştırıldı ve çok fazla kişiyi 
kapsayan bir simülasyon yaşandı. Gerçeklik dijital ekranlardan gerçekçi biçimde sunuldu. Pandemi dönemi ile birlikte uzaktan eğitim ilgi çekici hâle geldi. Öğrenciler tarafından pandemi dönemi öncesinde boş vakit geçirme ve eğlence içeriklerine ulaşmak için kullanılan ekranlar eğitim aracı haline dönüştürüldü.

Bu ekranlardan ilki televizyondur. Tüm dünya devletleri ile birlikte Türkiye'de eğitim içeriklerine bütün öğrencilerin ulaşabilmesi için ulusal eğitim kanalları açmıştır. Televizyonun hemen her evde olması yani yaygınlığ uzaktan eğitim açısından ilk tercih edilen mecra olmasını sağlamıştır. Televizyonun en önemli özelliği görselliğidir. Görüntünün gücü iletişim çağının belirleyicisi olmuştur. İletişim çağının en önemli unsuru iletişim araçlarıdır. İletişim araçları sayesinde dünyanın her yerine ulaşılması mümkün olmuş, pek çok alanda kullanılmıştır. Eğitim alanında da uzun yıllardan bu yana kullanılmaktadır. Dolayısıyla eğitim alanında uzaktan erişim konusunda tecrübeler bulunmaktadır. Türkiye' de 1980'li yıllarda okuma yazma seferberliği ile başlayan süreç daha sonra üniversite öğrencileri için açı öğretim dersleriyle devam etmiş ve televizyon üzerinden asenkron eğitimin temelleri atılmiştır.

“OECD'nin 2020 raporuna göre; Arnavutluk, Brezilya, Yunanistan, Kosova, Karadağ, Fas, Türkiye ve Vietnam'da her dört öğrenciye bir (oran = 0.25) veya daha az bilgisayar düşmektedir" (Reimers \& Schleicher, 2020: 21). $\mathrm{Bu}$ veriler erişim olanağı nedeniyle televizyon ekranının önemini işaret etmektedir. Televizyon; uzun bir süredir hemen her evde yer alması, eğitim alanında daha önceden kendini ispatlamış olması, ucuz maliyetli ve ulaşılabilir olması nedeniyle varlığını sürdürmektedir.

Televizyon aracılığıyla yapılan senkron dersler internet uygulamaları ile desteklenmektedir. Pandemi döneminde televizyon ekranı öğrencilere alı̧̧mış oldukları etkileşimli asenkron iletişimi sağlayamayınca diğer ekranlar devreye girmiştir. Bilgisayar, tablet ve telefon ekranları mobil olmaları ve asenkron eğitime olanak sağlamaları nedeniyle yoğun olarak kullanılmıştır. Tabii bunu sağlamada son on yıldır video akış hızındaki artışın ve internet altyapısının etkinleştirilmesinin etkisi bulunmaktadır. Yeni Medya eğitim alanında performatif yapısıyla görselleştirme ve simülasyona uygun içeriği desteklemektedir. Eğlence içeriklerini izlemeye alıştığımız televizyon ise bu uygulamaların yanında eski bir mecra olarak kalmıştır. Ancak eğitim aracı 
olarak her iki mecra da kullanılmıştır. Pandemi döneminde Türkiye'de anaokulu, ilköğretim ve orta öğretim öğrencileri temel bazı derslerinden geri kalmamaları için TRT üzerinden EBA TV kanalları devreye sokularak uzaktan senkron dersler yapılmış, internet üzerinden oluşturulan EBA sistemiyle de hem verilen derslerin yeniden izleme olanağı sağlanmış, hem de öğrenciler bireysel olarak da takip edilmeye başlanmıştır. Buradaki simülasyon normal eğitim dönemi bittikten sonra yaz aylarına da taşınarak, ileride bu tür uygulamaların devam edeceğinin sinyallerini vermiş̧tir. Uzaktan eğitimde EBA devlet tarafindan bir alternatif olarak yaşatılmaya devam etmektedir.

Pandemi döneminde rastgele seçilen fotoğraflar üzerinden yapılan betimsel analizde; Türkiye'de anaokulundan üniversiteye kadar olan geniş bir yelpazede yaklaşık yirmi milyon örgün eğitim alan öğrencinin dijital ekranlar aracılığıyla sanal sinfflara taşındığı gözlenmektedir. 1980'li yıllardan beri eğitim içeriklerinin paylaşıldığı televizyon ekranının yanında bilgisayar, tablet ve telefon ekranlarından içerikler takip edilmektedir. Bu içeriklerin oluşturulup ekranlardan paylaşılma sürecinin arkasında dijital altyapı ve içeriklerin dağıtıldığı donanım da önemli bir unsurdur. Pandemi döneminde sağlıktan sonra en fazla kişiyi etkileyen ve ilgilendiren konu eğitimdir. Pandemi eğitim alanında teknoloji kullanımı konusunda eksikliği öne çıkarmıştır. Çünkü eğitimin ekranlar aracılığı ile sunumu altyapı, donanım ve içerik olmak üzere üç bileşenli bir yapıdır.

Çalışmada; her yaş grubundan öğrencinin simülasyon evrenindeki teknolojik dönüşümün simülarkını oluşturduğu varsayılmış, bu evrende teknolojik dönüşümlerin ekranlar aracılığıyla yaratılmaya çalışıldığı düşünülmüş, bu durum fotoğraflar aracılığıyla gösterilmiştir. Anaokulu öğrencilerinin EBA ve internet uygulamaları üzerinden, ilkokul öğrencisinin EBA TV adı verilen Milli Eğitim Bakanlığı - TRT'nin işbirliği ile TRT bünyesinde yer alan televizyon kanalını izleyerek, orta öğretim öğrencilerinin yine EBA arayüzü üzerinden EBA TV ve sosyal medya uygulamalarını birlikte kullanarak, üniversite öğrencilerinin sosyal medya uygulamalan üzerinden görüntülü ve sesli katılımının olduğu sanal sınıf uygulamaları ile eğitim aldıkları gözlenmektedir. Pandemi döneminde her eğitim kurumunda ve her seviyede farklı sanal uygulamalar göze çarpmaktadır.

Pandemi döneminde tüm dünyada olduğu gibi Türkiye'de de örgün eğitimin uygulanamaması neticesinde uzaktan dijital eğitim uygulamaları ana öğrenme kaynağı olarak uygulamaya konulmuştur. Türkiye'de yaklaşı 20 
milyon, dünyada da 1,5 milyar öğrenci bu durumdan etkilenmiş, gelişen bu durum karşısında eğitim-öğretim konusunda dijital uygulamaların kullanılması gerekli olmuştur. Bu konuda dünyada uzaktan eğitim programları planlamak ve herkesi harekete geçirmek için devlet kurumları, ebeveynler, öğretmenler, öğrenciler ve yöneticiler olmak üzere hedeflenen tüm gruplar için uzaktan eğitim konusunda farkındalık kampanyaları veya iletişim stratejileri başlatılmış, Arjantin, Hırvatistan, Çin, Kosta Rika, Fransa, İran İslam Cumhuriyeti, Kore Cumhuriyeti, Meksika, Ruanda, Suudi Arabistan, Senegal, İspanya, Peru, Tayland ve Vietnam gibi ülkelerde öğretmenler ve öğrenciler arasındaki iletişimi sürdürmek amacıyla eğitim için ayrılan televizyon kanalları dışında sürekli öğrenme için çevrimiçi platformları ve mevcut internet uygulamaları devreye sokulmuştur.

Pandemi dönemi tarihsel anlamda mutlu sondan çok yeni bir başlangıç gibi görünmektedir. Pandemi döneminde dünyada ve Türkiye'de yaşanan gelişmeleri ve dönüşümleri ayrıca ele alıp değerlendirmek gerekmektedir. Yapılan çalışma durum tespitine yönelik ana çerçevenin çizildiği, ilerideki çalışmalara ışık tutması amacıyla yapılmıştır. Pandemi dönemindeki uzaktan eğitimi detaylı olarak değerlendirmek için erken olduğu düşünülmektedir. Bu büyük bir dönüşümdür. Castells'in sözünü ettiği yeni bir çağın, kültürün varoluşumuzdaki somut temelleri karşısındaki özerkliğinin damgasını vurduğu Enformasyon Çağı'nın başlangıcıdır (2008: 632). Kuşkusuz bu başlangıç bir anda bir anda bütün alışkanlıkları yerinden edecek ve sistemi kökünden değiştirecek kudrette değil ama geleceğin küçük bir simülasyonu olarak görülebilir. Simülasyon gerçeğin modellemesidir. Modellemede bir takım toplumsal ve kültürel dinamikler yapıyı belirler. Yani yerel bilinç ve kavramsallaştırma modelin oluşmasında önemlidir. Burada esas üzerinde durulması gereken nokta; yerel dinamiklerde gözetilerek simülasyon düzeninin bir anda simülarka dönüşmemesi, olumluya evrilmesidir. Yüz yüze gerçekleştirilen örgün eğitimin biricikliğini ortadan kaldıracak olsa da ölçme değerlendirmeye olanak sağlayan teknolojik yeni dijital eğitim sistemi ekranlar arac1lığıyla önümüzde günlerde de kullanılmaya devam edecek gibi görünmektedir. Ders materyalinin değişimi ve alışılan sistemden farklı bir izlek oluşturmak biraz zaman alacaktır. Ancak henüz geçiş döneminin yaşandığı kabul edilmesi gereken bir durumdur.

Pandemi dönemi ve sonrasındaki gelişmeler hem Türkiye'de hem de dünyada farklı bir evre olarak yeniden ele alınacak ve değerlendirilecektir. 
Son gelişmeler geleneksel öğrenme yöntemlerindeki yetersizlikleri gün yüzüne çıkarmış, uzaktan eğitimin bir ihtiyaç olduğunu göstermiştir. Örgün eğitimin her kademesinde açık ve uzaktan eğitim ile desteklenmesinin gerekliliği ortaya çıkmıştır. Post modern dönemde eğitimin her aşamasında uzaktan ve etkileşimli eğitimin deneyimlenmektedir. Eco'nun dediği gibi, bilginin keşfedici ve güven vermeyen kestirme yolları denemeye cesaret eden yapısı sayesinde ilerleme kaydettiği göz ardı edilmemelidir (2001: 92).

Yapılan çalışmada; dijital ekranlar aracılığıyla gerçekleştirilen uzaktan eğitim uygulamalarına ilişkin bir değerlendirme yapılmıştır. Teknoloji eğitim alanındaki dönüşümü şekillendirmekte en önemli etkendir. Ancak Türkiye açısından bakıldığında, yaklaşık yirmi milyon öğrenciyi ilgilendiren bir projede dönüşümü sağlamak hemen gerçekleşecek gibi görünmemektedir. Kısa, orta ve uzun vadede yapılacaklar listesi oluşturmak, kriterler geliştirmek ve bunları ayrı ayrı değerlendirilmek teknolojik izlek açısından önem taşımaktadır. Uzun erimde dünyadaki genç nüfusun azaldığı dolayısıyla ekonomiden büyük pay alan ve uygulanagelen eğitim sistemi yatırımlarının verimsizleştiği söylenebilir. Türkiye İstatistik Kurumu'nun 2020 verilerine göre, yıllık nüfus artış hızı 2018 yılında binde 14,7 iken, 2019 yılında 0,8 puan daha gerileyerek binde 13,9 (TÜIKK, 2020) olmuştur. Ekonomik altyapılarını nüfus artışına göre düzenleyen devletler eğitim alanında değişim ve dönüşüme gitmek durumundadır. Dolayısıyla eğitim alanında dijital dönüşme gitmek şart gözükmektedir. Mevcut koşullarda pandemi döneminin huzlandırıc bir etkisi olmuştur. Bundan sonra oluşan yeni ortamda dijital dönüşümün hız kesmeden tamamlanması gereklidir.

Gelecek teknoloji bağlamında çok parlak durmaktadır. Yakın gelecekte eğitimin tamamen dijital olması ve ardından da dijital ekranlar aracilığıyla uzaktan erişimle yürütülmesi kaçınılmazdır. Ancak unutulmaması gereken merkeze eğitim düşüncesinin alınması gerekliliğidir. 'Akıllı toplum' teknolojiyi kullanmayı ve yönetmeyi bilen insanların varlığıyla oluşacaktır. Bugün de, bir sonraki nesilde de teknolojiyi yaratacak, geliştirecek ve uygulayacak olan insandır. Bu nedenle öğrencilerin teknoloji ile dolayımlanmış iyi bir eğitim alması gerekliliği odağa yerleştirilmesi gereken en önemli noktadır. 


\title{
EXTENDED ABSTRACT
}

\section{The Effect of Pandemic Period on the Technological Transformation of Education on Screen \\ *}

\author{
Esennur Sirer \\ Üsküdar University
}

As technology has advanced and digital applications entered the field of life, efforts of transitioning to digitalization have also started in the field of education. Pioneering studies on this topic used to position technology usage as a supportive element in education. The days of pandemic that are experienced seem to open the way for restructuring of the education system in the context of technology. In this short period, technology usage has been tried with different practices. In this period where visuals become prominent, as in the simulation universe of Baudrillard, new education contents have been formed, and these contents have been tested via screens. That is, a simulation of access to education was created via technology. Screens, which used to be utilized by students for spending free time and accessing entertainment content before the "pandemic period", have turned into a tool for education. In this context, the question whether or not habits could be changed in the 'Post-corona' period arises.

This study discusses the issue of carrying approximately twenty million students receiving formal education in a broad spectrum from preschool to university into virtual classrooms via digital screens. The hypothesis of the study is the assumption that students from all age groups constitute the simulacra of the technological transformation in the simulation universe. It was aimed to prove that technological transformations are attempted to be created via screes in this universe. In the study, it was observed that education was received with virtual classroom applications involving visual and auditory participation by preschool students via internet applications, by primary school students via watching the television channel named EBA TV under the TRT (Turkish Radio and Television) in cooperation between the Turkish Ministry of National Education and TRT, by high school students via using EBA TV and internet applications together and by university students via internet applications. In the findings of the study, it was determined that interactive new media applications were used more than television screens. New 
media supports visualization and content suitable for simulation with its performative structure in the field of education. Television, on which we are used to watch entertainment content, has stayed as an outdated ecosystem besides these applications. Nevertheless, it was observed to continue its existence as it has been present at almost all homes for a long time, it has previously proven itself in the field of education, and it is inexpensive and accessible.

Based on the situation in Turkey, it may be stated that the transformation experienced in the field of education in the pandemic period is simulated in the entire world. As before, every country will determine its education policy by itself. However, directed digital education tested via digital screens seems to have opened new horizons in this issue. Although there might not be an immediate transition to the 'iTeach' period in the near future, digital screens provide a reference for the future.

In the historical sense, the corona era is seen as a new beginning rather than a happy ending. The beginning of a new era mentioned by Castells, the Information Age imprinted by the autonomy of culture against its tangible foundations in our existence (2008, p.632). Without a doubt, this beginning does not have enough power to immediately replace all habits and substantially change the system, but it may be seen as a small simulation of the future. The main point that needs to be focused on here is that the simulation order does not immediately turn into a simulacrum but evolves into what is positive. Although it will eliminate the uniqueness of formal education carried out face to face, it seems like the technological, new digital education system that allows measurement and assessment will continue to be used in the future via screens. As stated by Eco, it should not be neglected that knowledge advances thanks to its structure which is brave enough to try exploratory and untrustworthy shortcuts (2001, p.92).

As the young population gets smaller in the world, education system investments that take a large share from the economy become inefficient. States that organize their economic infrastructures based on population increase have to go into changes and transformations in the field of education. Technology is the most significant factor in shaping this transformation. However, looking from the perspective of Turkey, achieving transformation in a project that concerns approximately twenty million students does not seem to happen immediately. Forming a to-do list for the short, medium and long runs, 
developing criteria and separately assessing these carry importance in terms of the technological path.

The future seems very bright in the context of technology. However, what needs to be kept in mind is the necessity of placing the education philosophy into the center. The 'smart society' will be formed by the existence of people who know how to use and manage technology. People are who will create, develop and apply technology not only today but also in the next generation. For this reason, the necessity for students to receive a good education mediated with technology is the most important point of focus.

\section{Kaynakça / References}

Akmeşe, Z. (2020). Televizyonda çerçevelemenin içerik ve anlam üretimine etkisi. Ed. E. Sirer Televizyon 4.0 Toplum 5.0 Döneminde Yeni İzlence Yeni İzler Kitle içinde (s.203-219). Konya: Literatürk Yayınevi..

Altunay, A. (2015). Bir sosyalleşme aracı olarak yeni medya. Selçuk Illetişim Dergisi. 9 (1), 410-428.

Arda, Ö. (2020). An assessment of the new media documentary. OPUS International Journal of Society Researches, 15(24), 2937-2956. DOI: 10.26466/opus.678458

Aydoğan, İ. vd. (28-30 Eylül 2005). Baudrillard'ın simülasyon evreninde bir simülark olarak eğitim ve eğitim örgütleri. XIV. Ulusal Eğitim Bilimleri Kongresi'nde sunulan bildiri özeti. https://www.pegem.net/akademi/kongrebildiri detay.aspx?id=100510 adresinden erişilmiştir.

Aziz, A (1977). Türkiye'de radyo ve televizyon ile eğitim uygulamaları. Eğitim ve bi$\mathrm{lim}$. http://egitimvebilim.ted.org.tr/index.php/EB/article/view/5576 adresinden erişilmiştir.

Bajcsy, R. (2002). Technologies and learning. Vision 2020 Transforming Education and Training Through Advanced Technologies, September 9, 2002, Washington, D.C.

Baudrillard, J. (2018). Simülakrlar ve simülasyon. Çev. O. Adanır. Ankara: Doğu Batı Yayınları.

Baudrillard, J. (2012). Neden her şey hala yok olup gitmedi?. Çev. O. Adanır. İstanbul: Boğaziçi Üniversitesi Yayınevi.

Baudrillard, J. (2004). Tam ekran. Çev. B. Gülmez. İstanbul: Yapı Kredi Yayınları.

Baudrillard, J. (1991). Sessiz yı̆̆ınların gölgesinde ya da toplumsalın sonu. Çev. O. Adanır. İstanbul: Ayrunt Yayınevi.

Binark, M., ve Gencel Bek M. (2010). Eleştirel medya okuryazarlığı kuramsal yaklaşımlar ve uygulamalar. İstanbul: Kalkedon Yayınları. 
Bolat, N. (2020). Televizyonun teknik dönüşümünün içeriğe etkisi. Ed E. Sirer. Konya Televizyon 4.0 Toplum 5.0 Döneminde Yeni İlence Yeni İzler Kitle içinde (s. 107127), Literatürk Yayınevi.

Burton, G. (1995). Görünenden fazlası. Çev. N. Dinç. İstanbul: Alan Yayıncılık.

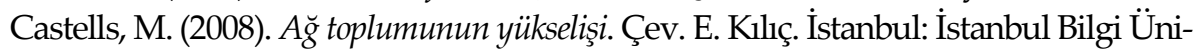
versitesi Yayınları.

Çakır, M. (2014). Görsel kültür ve küresel kitle kültürü. Ankara: Ütopya Yayınevi.

Çelik, Z. (Mayıs 12, 2020). Pandemi sonrası dünyada ve türkiye'de eğitim. Perspektif Online. https://www.perspektif.online/pandemi-sonrasi-dunyada-ve-turkiyede-egitim/

EBA rekor tazeledi: 1.2 milyon tik (07.05.2020). Hürriyet. https://www.hurriyet.com.tr/egitim/eba-rekor-tazeledi-1-2-milyon-tik-41512059 adresinden erişilmiştir.

Eco, Umberto (2001). Açık yapıt. Çev. P. Savaş. İstanbul: Can Yayınları.

Ellul, J. (2017). Sözün gözden düşüşü. Çev. E. Ercan. Bursa: Sentez Yayıncllk.

Enzensberger, H. M. (1979). Bir kitle iletişimi araçları teorisi'nin oluşturucu ögeleri. Çev. Ü. Oskay. İstanbul: Birikim Yayımcllk. No.58-59. 17-37.

Ertuğ, C. (2020). Coronavirüs (Covid-19) pandemisi ve pedagojik yansımaları: Türkiye'de açık ve uzaktan eğitim uygulamaları. Anadolu Üniversitesi Açıköğretim Uygulamaları ve Araştırmalarn Dergisi. 6(2), 11-53.

Eurydice Report (2019). Digital education at school in Europe. European Commission Jenkins, H. (2018). Cesur yeni medya. Çev. N. Yeğengil. İstanbul: İletişim Yayınları.

Jones, K. (17 Şubat 2020). How technology is shaping the future of education. https://www.visualcapitalist.com/how-technology-is-shaping-the-futureof-education/

Karadağ, E. ve Cemil Y. (2020). Yeni tip koronavirüs pandemisi döneminde üniversitelerde uzaktan eğitim: lisans öğrencileri kapsamında bir değerlendirme çalışması. Yükseköğretim Dergisi. Yayımlanmış makale.

Karapınar, A. (2017). Gerçeklik ve hiper gerçeklik: Baudrıllard ve G. Debord anlatılarından hareketle hakikatin yeniden inşası. Uluslararası Sosyal Araştırmalar Dergisi. 10(53).

Maarif UNYT Üniversitesi'nde uzaktan eğitim başladı (Mart 17, 2020). Anadolu Ajansı https://www.aa.com.tr/tr/sirkethaberleri/egitim/maarif-unyt-universitesinde-uzaktan-egitim-basladi/656295 adresinden erişilmiştir.

MEB Eğitim Öğretim İstatistiklerini Açıkladı (07.09.2019). Anadolu Ajansı. https:/www.aa.com.tr/tr/egitim/meb-egitim-ogretim-istatistiklerini-acikladi/1575243 adresinden erişildi. 
Metin, O. ve Karakaya, Ş.(2017). Jean Baudrillard perspektifinden sosyal medya analizi denemesi. Afyon Kocatepe Üniversitesi Sosyal Bilimler Dergisi, 19(2), 109-121. Milli Eğitim Bakanlığı (28 Mart 2020). Eba kontrol merkezi ile uzaktan eğitim 7/24 yakm takipte. https://www.meb.gov.tr/eba-kontrol-merkezi-ile-uzaktan-egitim724-yakin-takipte/haber/20599/tr adresinden erişilmiştir.

Ong, W. (2002). Orality and literacy the technologizing of the word. New York: Routledge. Önk Ürün, Y. (2009). Baudrillard perspektifinden bir kitle iletişim ve sanat aracı olarak simülasyon evreninde televizyon. Selçuk İletişim, 5(4), 201-218.

Özdestici, H. (14 Mayıs 2017), Toplum 5.0: Teknolojik gücü doğru yönetecek akıllı toplum felsefesi. Webrazzi. https://webrazzi.com/2017/05/14/toplum-5-0/ adresinden erişilmiştir.

Özel, S. (2018). Televizyon yayınlan için mobil girişimler. Ed. M. Gürer, Televizyon Çalışmaları. İstanbul: Der Yayınları.

Pandemi nedir, ülkeleri nasıl etkiler? (Şubat 24, 2020). BBC News. 12 Mart 2020 tarihinde https://www.bbc.com/turkce/haberler-dunya-51614548 adresinden erişilmiştir.

Postman, N. (1994).Televizyon: Öldüren eğlence.Çev. O. Akınhay.İstanbul: Ayrıntı Yayınları.

Reimers, F. M. ve Schleicher, A. (2020). 2020 COVID-19 pandemisine karşı eğitimde atılabilecek adımlara rehberlik edecek bir çerçeve. OECD 2020 Raporu. https://globaled.gse.harvard.edu/files/geii/files/framework guide v4 tr.pdf adresinden erişilmiştir.

RTÜK (2019). Televizyon izleme eğilimleri araştırması. https://www.rtuk.gov.tr/assets/Icerik/AltSiteler/televizyonizlemeegilimleriarastirmasi2018.pdf

Sanders, B. (2010). Öküzün a'sı elektronik çağda yazılı kültürün çöküşü ve şiddetin yükselişi. İstanbul: Ayrintı Yayınları.

Sirer, E. (2020). Zamanın Ruhu: Eşzamansızlık. Ed. E. Sirer Televizyon 4.0 toplum 5.0 döneminde yeni izlence yeni izler kitle. İçinde (s.49-65).Konya: Literatürk Yayınevi.

Tuğrul, F. (12 Aralık 2019). Türkiye'nin çocuklarının dijital yolculuğu. Mediabranda Insight (MBI) Çocuk Araştırmaları Koordinatörü. TRT Uluslararası Çocuk Medyası Konferansı Sunumu.

TÜİK(2020). Temel Istatistikler. http://www.tuik.gov.tr/UstMenu.do?metod=temelist adresinden erişilmiştir.

Van Dijk, J. (2018). A ̆̆ toplumu. Çev. Ö. Sakin. İstanbul: Epsilon Yayınevi.

Velilerin Uzaktan Egitim Deneyimi (Mart 25, 2020). Bianet http://bianet.org/cocuk/egitim/221951-velilerin-uzaktan-egitim-deneyimi-eba-ya-erisim-saglayamiyoruz adresinden erişilmiştir. 
We are Social (2020). Dijital in 2020. https://wearesocial.com/digital-2020 adresinden erişilmiştir.

We Are Social Digital 2020 raporunda Türkiye özelinde öne çıkanlar (2020). Webrazzi, https://webrazzi.com/2020/02/03/we-are-social-digital-2020-raporunda-turkiye-ozelinde-one-cikanlar/ adresinden erişilmiştir.

Williams, R.S. (2002). Future of education = Technology + teachers. Vision 2020 Transforming Education and Training Through Advanced Technologies, September 9, 2002, Washington, D.C.

World Education Blog (24.03.2020). How are countries addressing the Covid-19 challenges in education? A snapshot of policy measures. https://gemreportunesco.wordpress.com/2020/03/24/how-are-countries-addressing-the-covid-19-challenges-in-education-a-snapshot-of-policy-measures/ adresinden erişilmiştir.

Yamamoto T, G. ve Altun, D. (2020). Coronavirüs ve çevrimiçi (online) eğitimin önlenemeyen yükselişi. Üniversite Araştırmalan Dergisi, 3(1), 25-34.

TRT Arşiv. (2020). 1983'te Okuma-yazma seferberliği. Youtube[VideoBlog]. https:/www.youtube.com/watch?v=VTj-D262M14 adresinden erişilmiştir.

Yüksek öğretim bilgi yönetim sistemi (2020). Yüksek öğretim istatistikleri. https://istatistik.yok.gov.tr/

Yüksek Öğretim Kurumu (26.03.2020). Basın bülteni. https://www.yok.gov.tr/Sayfalar/Haberler/2020/YKS\%20Ertelenmesi $\% 20 \mathrm{Bas} \% \mathrm{C} 4 \% \mathrm{~B} 1 \mathrm{n} \% 20 \mathrm{~A} \% \mathrm{C} 3 \% \mathrm{~A} 7 \% \mathrm{C} 4 \% \mathrm{~B} 1 \mathrm{klamas} \% \mathrm{C} 4 \% \mathrm{~B} 1 . \mathrm{aspx}$ adresinden erişilmiştir.

Yüksek Öğretim Kurumu (29.03.2020). Basın bülteni. https://www.yok.gov.tr/Sayfalar/Haberler/2020/universitelerde-uygulanacak-uzaktan-egitime-iliskinaciklama.aspx adresinden erişilmiştir.

Zahn, M. vd. (2019). Education in the age of the screen possibilities and transformation in tecnology. Routledge. $\quad$ https://www.researchgate.net/publication/335003831 Education in the Age of the Screen Possibilities and Transformations in Technology

\section{Kaynakça Bilgisi / Citation Information}

Sirer, E. (2020). Eğitimin ekran üzerinden teknolojik dönüşümünde pandemi dönemi'nin etkisi. OPUS-Uluslararası Toplum Araştırmaları Dergisi, 16(29), 1987-2018. DOI: 10.26466/opus.777215 